\title{
Historical Consciousness and Perception of National History by Kazakhstan Youth in the 20th Century
}

\author{
Nikolay Sergeevich Lapin and Maral Serikovna Tomanova* \\ The Institute of State History of the Science Committee of the Ministry of Education and Science of the Republic of \\ Kazakhstan, Astana, Kazakhstan; lapin.79@mail.ru; maral-kz@list.ru
}

\begin{abstract}
Background: The purpose of this research is to analyze peculiarities of perception of the events of national history of the $20^{\text {th }}$ century by youth and citizens of Kazakhstan in general, which will help find out particularities of Kazakhstan's people historical consciousness formation in the modern period. Methods: Methodological basis for sociological measurement of Soviet and post-Soviet history perception was made by massive questionnaire surveys in nationally representative samples in post-Soviet countries. The main block of questions was designed centrally in the Russian language. Then, in each country including Kazakhstan, the questionnaire was supplemented with specific blocks concerning the events and persons important for the history of the country but which seemed to be little known abroad. Findings: The analysis of sociological data indicated that the number of young Kazakhstani knowing the history of their country or region is less than the number across the entire population. Young people of Kazakhstan and post-Soviet countries are less informed about events remotely connected with the realm of their personal experience and history of the Soviet period than the whole population in general. Comparison of data on the perception of the Soviet history ideologemes, i.e. established collocations having an ideological assignment by youth and adult population of Kazakhstan and post-Soviet countries have not detected serious differences between them. During the comparison of data related to the perception of ideologemes of Soviet history no serious differences have been found in their perception by youth or adults. Historical consciousness of Kazakhstan's youth and population in general reflects rather their concept than their basic knowledge of historical facts. Application: The findings of the study will be helpful for specialists who deal with the issues of historical consciousness and perception of the national history.
\end{abstract}

Keywords: Historical Consciousness, Historical Education, Historical Figures, Kazakhstan, Youth

\section{Introduction}

The purpose of this research is to analyze peculiarities of perception of the events of national history of the $20^{\text {th }}$ century by youth and citizens of Kazakhstan in whole. Determination of this question will help to find out particularities of formation of Kazakhstan's people historical consciousness in the modern period.
Analysis of research publications shows that the study of historical consciousness has significant development in modern science, i.e., philosophy, history, sociology, political science. This makes the scientific study of this question in Kazakhstan and in the former Soviet Union actual.

The research area clearly shows the need for complex interdisciplinary investigation. The results can be obtained using methods and practices of the humanities 
and social sciences, and first of all of history and sociology.

Researchers specify the study of historical consciousness and historical memory as a part in sphere of interest for sociology (historical sociology) ${ }^{1}$.

Solution for the range of issues including related aspects of the history and sociology provides, on the one hand, an opportunity to introduce clearer description of historical consciousness as an element of social consciousness, and, on the other hand, to emphasize the specific features and special characteristic of this form of consciousness and to identify ways to research it.

Sociology, in contrast to philosophy, is not a study of theoretical level of social consciousness, but the consciousness functioning in reality expressed in the positions of certain people. In research process sociologists seek information from people themselves, and they are faced with the fact that every single object of research - a person or a group of persons - is a combination of both partially scientific and finitely everyday perceptions about the course of history in general, or the history of a particular country or any territory, etc. Academic studies show that major historical events relating to the country, social strata and groups, individual and some problems in the life of the people often make the object of researchers' attention.

At the same time historical consciousness may cover important and random events, absorbs itself as systematic information, most often through the system of school education ${ }^{2}$ as well as completely disordered information received through literature or media. In addition, orientation to the accumulation of information is determined by interests or aptitudes of one person. It is necessary to agree with experts who attach importance in functioning of historical consciousness to information received accidently, often mediated through culture of people, families surrounding individual, as well as perhaps through customs and traditions, which can carry a certain conception of people, the country and the state's life. Let us add that official and semiofficial interpretation of the events, literary and personal assessment of state and public figures leave their imprint on the historical perception, and many of them were repeatedly reviewed with regard to changes in the political life of the country, and for a short period of time ${ }^{3}$.

On the other hand interdisciplinary approach and specifically an appeal to the study of historical consciousness from the perspective of different disciplines resulted in several definitions for "historical consciousness" which do not always correspond to each other.

For example, Sirkka Ahonen ${ }^{4}$ believes that the historical consciousness means successive mental orientation in the course of time. This orientation is based on the human ability to think forward and backward in time. In addition, the "historical consciousness means an interaction between making sense of the past and constructing expectations for the future". Andrew Glencross gives a somewhat different definition ${ }^{5}$. According to Glencross historical consciousness means understanding the nature of historical experience, which is past, present and future connected together to obtain the historical knowledge.

According to $\frac{1}{}$, historical consciousness as well as historical memory is a part of public consciousness "a kind of reflection of historical experience in people's consciousness and behavior which formed actually functioning values".

J. T. Toshchenko $\mathrm{o}^{\frac{3}{}}$ gives the similar characteristics of historical consciousness. In his assessment this type of social consciousness is a set of ideas, views, perceptions, feelings, moods, reflecting the perception and assessment of the past in its variety, typical for society as a whole and for various demographic, professional and ethnic groups as well and for individuals too.

Various scholars give numerous definitions of historical consciousness: it is a synonym for the collective memory to some extent; $\underline{-6}$ "historical consciousness is not just a set of knowledge, perceptions and ideas of the past, but especially knowing certain contexts (let us say continuity, discontinuity and changes) between the past (stored in the collective memory), the present and the future; it is consciousness that helps to create attitudes towards the present and the future"; ${ }^{\text {" }}$ "historical consciousness is defined as the area in which collective memory, the writing of history and other modes of shaping images of the past in the public mind merge"; $;$ it is also described as a special form of historical memory asserting their identity". "Specificity of historical consciousness is that the time perspective where past is connected with present and present is connected with future, has been designed in a more complicated way. Historical consciousness pushes past from the present giving it the appearance of something else"

Also there are other definitions that characterize historical consciousness as a collective memory. ${ }^{10}$ Historical memory as a cell of historical consciousness has an ability to restrain the main historical events in people's 
conscious, herewith so much so that this leads to transformation of concrete historical knowledge to different forms of worldview perception of past experience and its fixation, for example in legends, tales, fables ${ }^{3}$.

Summarizing the above, the authors tried to formulate their definition of historical consciousness. In our opinion, historical consciousness, as researchers recognize, is a form of public consciousness, which at bottom, is summation of such elements as historical memory and conceptualizing of historical experience (independently from scales). Structurally, historical consciousness is divided into individual, group and collective.

Such peculiarity of historical memory as selectiveness should be mentioned, i.e. when an extravagance takes place in individuals' consciousness - exaggeration of certain moments of historical past or straight conversely, seemingly important historical events and historical persons are reflected weakly or not reflected at all in the memories of individuals or groups.

\section{Methodology}

The article contains the study and analysis of materials received in 2009 for the project "Perception of Soviet and post-Soviet history by the young people of newly independent states" $" 11$. The project was performed on the basis of a regular cross-country population surveys system "Eurasian Monitor". To date it is the only large-scale study on the issues of historical consciousness and historical memory that was held in Kazakhstan and the former Soviet Union.

Methodological basis for sociological measurement of young people and the whole population's perception of Soviet and post-Soviet history were massive population surveys in nationally representative samples in post-Soviet countries. The surveys were conducted in the form of full-time formal interviews using questionnaire. The main ("general") block of questions for mass surveys was designed centrally in the Russian language. Then, in each country including Kazakhstan the questionnaire was completed with specific blocks concerning the events and persons important for the history of the country but which seemed to be little known abroad. Final version of questionnaire was translated into the main national languages of each country participating in the project.

Regarding the historical characters the survey makes a list of historical figures consisting of two parts: general and national. The general part is fixed and includes 11 characters (Nicholas the II, V. Lenin, F. Dzerzhinsky, I. Stalin, G. Zhukov, N. Khrushchev, L. Brezhnev, M. Gorbachev, Y. Gagarin, A. Sakharov, B. Eltsin). This list is formed on the basis of expert assessments taking into account the results of the competition "Name of Russia" and due to the figures link to the major historical milestones of Soviet history. The national (specific) part is not fixed quantitatively (each of the countries-participants of the project made a list of 4 or more national figures, based on their own capabilities and needs), however, the developers of research toolkit sought to ensure that each particular unit includes the characters related to: 1) the "heroes" of the revolution and the civil war of 1917-1920,2) "antiheroes" of the same events (fighters against the Soviets), 3 ) the Soviet government and party figures, 4) figures of national culture of the Soviet period, 5) late Soviet or post-Soviet leaders.

This type of question allows assessing the level of respondents' awareness about common "Soviet" and specific "national" figures. It makes possible to measure the attitude of respondents and helps to identify intergenerational differences in the perception of "Soviet" and "national" figures.

In Kazakhstan national figures were presented by Amangeldy Imanov, Alikhan Bukeikhanov, Turar Ryskulov, Dinmuhamed Kunayev, Olzhas Suleimenov (see Figure 1). It should be noted that a specific block submitted by Kazakhstan does not fully comply with the above mentioned requirements as there was no item: 5) "the late Soviet or post-Soviet leaders".

Eleven events related to the fundamentally different stages of Soviet history were selected for the analysis of general perception of historical events concerning the Soviet period: the February Revolution of 1917 in the Russian Empire (the fall of the autocracy); Lenin and the Bolshevik Party's rise to power (October Revolution of 1917); political trials in 1937-1938, mass arrests, repression and executions of political prisoners; Germany's attack on the Soviet Union in June 1941 (the beginning of the Great Patriotic War of 1941-1945.); the surrender of Germany to the Soviet Union in May 1945 (Soviet Union's victory in the Great Patriotic War of 1941-45.); creation of Soviet nuclear missiles in the 50's; the conclusion of the Warsaw Pact in 1955, the formation of a military-political alliance of socialist states; the $20^{\text {th }}$ Congress of the CPSU in 1956, condemnation of the cult of Stalin's personality and political repression during his administration; the $22^{\text {nd }}$ 
Congress of the CPSU in 1961, the adoption of the program of building communism in the USSR; Restructuring and socio-economic reforms in the Soviet Union in 19851990; the collapse of the Soviet Union in 1991. In this article we use the data of average standardized assessment from brief analytical report "Perception of Soviet and post-Soviet history by the young people of newly independent states". Assessment of events was made by 5 -point scale ( 1 to 5 ). For data analysis the 5 -point scale was recorded to ordinal scale where " $-1,-0.5,0,+0.5,+1$ ", i.e. -1 (an extremely negative evaluation) to +1 (an essentially positive evaluation). As the report indicates that perception of Soviet history by young people is not different from that of population in a whole we use general data of the analytical report.

Former Soviet Union population and young people surveys in the framework of the $11^{\text {th }}$ wave of "Eurasian Monitor", including project "Perception of Soviet and post-Soviet history by the young people of newly independent states" were held during one month, from mid-April to mid-May 2009. According to technical requirements, at least 1,000 people representing adults (18 years and above) were supposed to be interviewed in each country, including at least 300 young respondents aged 18 to 30 years.

In accordance with the present rules of "Eurasian Monitor" project, responsibility for the representativeness of respondent samples and methodological correctness of the survey procedures (including translation into the appropriate languages, encoding, etc.) rests entirely on the companies performing national surveys.

In Kazakhstan the survey was conducted from the $20^{\text {th }}$ to $28^{\text {th }}$ April, 2009 by Center for Social and Political Investigations "Strategy" (Almaty).

\section{Results}

\subsection{Historical Consciousness in the Post- Soviet Space in 1990-2000}

First All-Russian research dedicated specifically to the study of the level of historical consciousness of citizens was the work of a research group led by V.I. Merkushina held in May - June 1990 (the number of respondents - 2,196 people). The study "Historical consciousness: situation and trends under conditions of perestroika" was the starting point for further polls in many ways. Since this study was conducted at the Centre for Sociological
Research of the Academy of Social Sciences under the Central Committee of the Communist Party - the party of higher educational institutions of the USSR, the results of this study became available to researchers much later. The first person to introduce these results in a scientific turnover was Zh.T. Toshchenko in $2000^{3}$.

According to the survey, in 1990 the most significant events for the people's fate were: the era of Peter I (the opinion of $72 \%$ of respondents), the Great Patriotic War (57\%), the Great October Socialist Revolution and the Civil War (50\%), the years of perestroika (38\%), the struggle against the Tatar-Mongol yoke (29\%), the period of Kievan Rus (22\%), the years after the abolition of serfdom (14\%), the period of NEP (12\%), industrialization, collectivization and cultural revolution (12\%), the reign of Ivan the Terrible, the reign of Catherine the II, and the first Russian revolution (11\% for each) ${ }^{3}$.

Historical personalities marked by respondents were presented in the survey as well. In particular the activities of Peter the I were positively estimated by $74 \%$ of the population, as for V.I. Lenin - 57\%, G.K. Zhukov - 55\%, Alexander Nevsky - 28\%.

In 1991, the Department of Sociology and Political Science of Moscow State Open Pedagogical University conducted a research of the problem of "historical consciousness of modern students". Target group included 481 people with representatives of one Moscow University and two regional universities in Tula and Cheboksary. As a result of this research the data of the mechanism of formation of historical consciousness of young people, the depth of the historical memory, attitudes and evaluation of historical events and historical figures were obtained.

One of the results obtained is connected to the attitude of young people to the historical figures of the $20^{\text {th }}$ century. The survey presented the following question: "Which of the statesmen of Russia in the $20^{\text {th }}$ century, in your opinion, had the greatest influence on the development of our country?" In the end the results were as follows: V.I. Lenin (50\%), M.S. Gorbachev (48\%), P.A. Stolypin (38\%), J.V. Stalin (37\%), B.N. Yeltsin (14\%). N.S. Khrushchev (8\%), Nicholas the II and L.I. Brezhnev (6\%), Y.V. Andropov $(4 \%)^{\frac{12}{2}}$.

As is well-known, in the context of unitary USSR the factual identical social-economic conditions existed in different parts of country, general (unitary) information and education space - educational program and training aids on history were established at the All-Union level and were the same. Consequently, in our opinion, the 
data received in the process of opinion measurement in regions of Russia will be able to coincide with the degree and character of historical consciousness in Kazakhstan of that time.

Subsequently, another series of studies was conducted in the post-Soviet space (in 1998 and 2004) in which the issues of formation of citizens' historical consciousness were considered in a varying degree ${ }^{13}$.

Generally, the attitude of Russian citizens to the Soviet period in the history is shifted to the positive rather than to the negative pole. It should be mentioned that this tendency remains stable for about 10 years. An important result of the study is also the conclusion that "the Soviet paradigm is not destroyed, nor yet practically impossible to be displaced from the mass consciousness" $\underline{13}$.

This is explained by the fact that the value of the primary level of historical knowledge - the family - is increasing and weakening of interest in world history is marked among the preferences ${ }^{14}$.

If to speak immediately about Kazakhstan, it is recognized that "sociological investigations on historical theme are not spread enough, and during last years, we had no possibility to conduct such survey" $\underline{15}$.

However, the works on investigation of historical consciousness were anyhow undertaken.

The Center for Social and Political Investigations "Strategy" in 2009 and 2011 years conducted the research, which touched upon an issue of perception of historical events and historical persons by the country population.

In 2009 the question about the most important historical events for the country in the 20th century (an exhaustive list was suggested, with 3 important variants for choice) was asked to experts and participants of a special focus-group.

According to comparative analysis, expert and common opinions strongly differ in valuation of events. If for the first category more important events include the acquisition of Independence, the Virgin Lands Campaign and famine in 1930 - 1933, so for the second one the most significant facts are the Victory in the Great Patriotic War and the closing of the Semipalatinsk nuclear test site (1991).

In 2011, the population and experts survey was conducted on the topic: "Which events in the country's history give rise to pride in you?"

According to results of this survey, both population and experts often gave the following answers: - the creation of Independent state - the Republic of Kazakhstan in 1991, participation of Kazakhstan's people in the Great
Patriotic War, the Virgin Lands Campaign, repulse of the Junggar invasion $\left(18^{\text {th }} \mathrm{c} .\right)^{15}$.

The investigation of the regional degree of historical consciousness and expansion of ethno-cultural values among citizens of East Kazakhstan was undertaken.

This investigation let present the self-evaluation of respondents about their knowledge of history of Kazakhstan, who estimated their knowledge as "good" $25.6 \%$, and "poor" $-21.6 \%$.

An interesting result was obtained by Konovalov A. concerning the difference of consciousness or knowledge of historical events between the whole population and young people. For example, as in the other cases, the highest degree of knowledge in population was as regards the events of the Great Patriotic War (the Second World War) - 85.2 from all surveyed, however among young people (up to 29 years) this index turned out to be less by $30 \% \frac{16}{16}$. Looking ahead, we must say that commensurable trends will be revealed at the level of entire country. This will demonstrate the analysis of the results of large research in 2009 , on the results of which this article is based.

\subsection{Youth Interest in History}

The declared level of interest of young people from newly independent states in the history of their own country is quite high $(71 \%)$, while the history of other former Soviet Union countries is interesting for them to a lesser extent (44\%), i.e., it is more than one and a half times lower than the average level of interest in the history of their own country).

Along with the question about the interest in the history of the home country or the former Soviet Union countries, respondents were asked to which extent they know the history of their own country in the $20^{\text {th }}$ century and the history of the USSR. The questions were as follows:

Can you say that you:

- are interested in the history of your country - 74\%;

- know the history of your country in the $20^{\text {th }}$ century $-71 \%$;

- are interested in the history of other countries of the former Soviet Union - 53\%;

- know the history of the USSR - $67 \%$.

\subsection{Results of the Survey Concerning the Historical Events}

The data referring to the whole population (an average normalized estimation of historical events related 
to the whole population and youth is provided in this paragraph): the February Revolution of 1917 - 0.2; the October Revolution of 1917 - 0.3; political trials in 1937 1938. - (-0.7); Germany attack on the USSR in June 1941 - (-0.8); the surrender of Germany to the Soviet Union in May $1945-0.8$; creation of Soviet nuclear missiles in the 1950s - 0.0; the conclusion of the Warsaw Pact in $1955-0.3$; the $20^{\text {th }}$ Party Congress in 1956, the condemnation of Stalin's personality cult -0.2 ; The adoption of the program of building communism in the USSR - 0.2; Reconstruction in 1985-1990 - (-0.1); the collapse of the Soviet Union in $1991-(-0.2)$; education in the USSR in 1922 - 0.5; national state delimitation of Central Asian Republics 1924-1925 and the formation of the Kazakh SSR - 0.4; collectivization and the transition from a nomadic lifestyle to a settled way of life in 1920-1930 - 0.4; development of virgin lands in 1954-1960 - 0.6; mass demonstrations of Kazakh youth in December 1986 "Zheltoksan-86" - 0.2; Kazakhstan independence gained in December $1991-0.8$.

The data referring to young people under thirty: the February Revolution of 1917 - 0.1; the October Revolution of 1917 - 0.2; political trials in 1937-1938 (-0.7); Germany attack on the USSR in June $1941-(-0.8)$; the surrender of Germany to the Soviet Union in May 1945 - 0.8; creation of Soviet nuclear missiles in the 1950s - 0.0; the conclusion of the Warsaw Pact in $1955-0.3$; the $20^{\text {th }}$ Party Congress in 1956, the condemnation of Stalin's personality cult -0.1 ; the adoption of the program of building communism in the USSR - 0.2 ; Reconstruction in 1985-1990 - 0.0; the collapse of the Soviet Union in 1991 - 0.0; education in the USSR in $1922-0.4$; national state delimitation of Central Asian Republics 1924-1925 and the formation of the Kazakh SSR - 0.4; collectivization and the transition from a nomadic lifestyle to a settled way of life in 1920-1930 - 0.4; development of virgin lands in 1954-1960 - 0.5; mass demonstrations of Kazakh youth in December 1986 "Zheltoksan-86" - 0.3; Kazakhstan independence gained in December 1991 -0.8.

Only 3 out of 11 historical events can be singled out which are not just well-known, but the level of their popularity is high in all countries of the former Soviet Union. On average, about $90 \%$ of the respondents from 14 participating countries reported that they had at least heard of:

- the German attack on the Soviet Union in June 1941;

- Surrender of Germany to the USSR in May 1945;

- the collapse of the Soviet Union in 1991.
Let us look at some of the findings in these events evaluation. The study showed that the average normalized score of Kazakhstan youth attitude to the German attack on the Soviet Union in June 1941 (the beginning of the Great Patriotic War of 1941-1945) is about 0.8. If we compare it with other countries the average normalized score of attitude to the event "The German attack on the Soviet Union" for young respondents in Tajikistan is about -0.6. In Estonia, Moldova, Latvia, Lithuania, Armenia, Kyrgyzstan, Azerbaijan the score is from -0.6 to -0.7. In Uzbekistan, Belarus, Georgia, Russia and Ukraine it is from -0.8 to -0.9 .

Comprehensive research has shown that the evaluation of the surrender of Germany to the USSR in May 1945 (i.e. the Soviet Union's victory in the Great Patriotic War of 1941-1945) is positive in general. Let us refer to the figures: the average normalized score for the total population of the Republic of Kazakhstan is 0.8 and the average normalized score related to young people under 30 is 0.8 as well. The results of this study show that the perception of the history of the Soviet period by young people is almost the same as the perception of population in the general. This is despite the fact that it was formed under conditions of independence and in a number of cases on the basis of a new vision of the history, reflected in new textbooks.

As the results of the study show, the average normalized score of Kazakhstan youth attitude to the event "The collapse of the Soviet Union in 1991" is about -0.05, so it is possible to say that in general young people of Kazakhstan give a negative assessment to the collapse of the USSR. The other 13 countries demonstrate interesting results: youth of Armenia, Belarus, Ukraine negatively evaluate the collapse with score ranging from -0.01 to -0.02 , youth of Kyrgyzstan, Russia, Tajikistan also react negatively to this event scoring from -0.02 to -0.04 . Youth of Moldova, Latvia and Azerbaijan (from 0.05 to 0.25 ) and young people in Uzbekistan, Estonia, Lithuania, Latvia, Georgia (from 0.4 to 0.6 ) express their positive attitude to the event "The collapse of the Soviet Union in 1991".

\subsection{Peculiarities of Perception of Outstanding Historical Persons by Kazakhstan's Youth}

As noted above, in the present study the characters of not only Soviet but also pre-Soviet and post-Soviet history were presented. Comprehensive research allowed receiving the following data shown in Figure 1. 


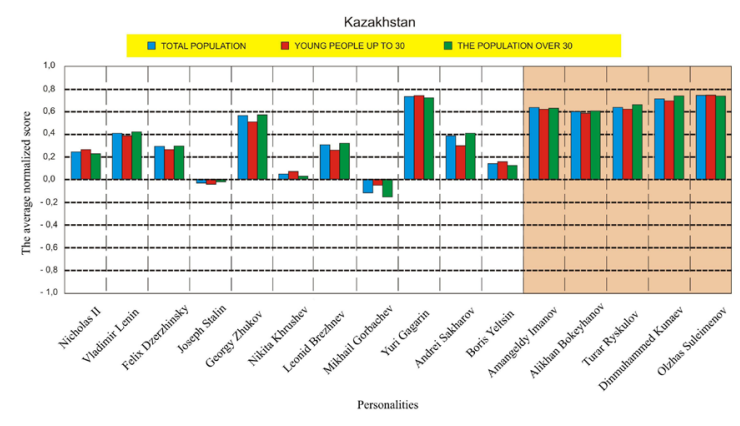

Figure 1. Average normalized estimate of historical figures in Kazakhstan.

Results of the research as well as the data of the previous block showed minor differences in the estimates of historical figures between the whole population and young people up to thirty years. For example, the last Russian Emperor Nicholas II has one of the lowest levels of fame - 0.2.

The Soviet period was marked not only with creation of the national industry but also with bringing some foundations of civilization. The Soviet era and its historical persons cause very positive feelings. Perhaps this is why almost three-quarters of the population of Kazakhstan (60\%) positively assess the personality of V. Lenin. The perception of youth is mostly similar to the perception of the entire population.

Level of recognition of another prominent personality of the Soviet era Felix Dzerzhinsky is relatively low (36\%).

The investigation showed that attitude to Stalin in Kazakhstan society is far from being unambiguous - 35\% give a positive evaluation and almost the same (36\%) evaluate him negatively. Another $20 \%$ of respondents declared their neutral attitude. It is worth noting that in general young people evaluate this historical character more negatively than population in general and the respondents of older age groups.

The $63 \%$ of respondents said about their positive attitude towards the person of Marshal Zhukov. The difference of awareness about the character depending on age should be noted: younger respondents, in general, are significantly less likely to have an idea about the historical figure than the older generation. Perhaps this explains the more restrained assessment of young people comparing with the entire population.
The results of investigation revealed almost the same high level of awareness of Y. Gagarin, regardless of the age of the respondents. A positive attitude to the first cosmonaut was expressed by $90 \%$ of participants, and differences in the estimates of older and younger generation were not revealed.

The attitude of Kazakhs to academician A. Sakharov is of particular interest: $33 \%$ assess him positively, $7 \%$ negatively, $18 \%$ are undecided and $14 \%$ declare their neutral attitude. A positive attitude is probably the consequence of a complex of reasons taking into account the contribution of A. Sakharov in the development of science and strengthening the defense of the USSR.

Negative assessment of N. Khrushchev was expressed by $19 \%$ of respondents; positive assessments were recorded for $30 \%$ and $34 \%$ of the respondents represented their neutral attitude to this character.

Noticeably more positive attitude was discovered for L. Brezhnev than to N. Khrushchev - $50 \%$ of respondents gave a positive assessment of his personality. If we compare the data obtained from other countries in the framework of this comprehensive survey, most of the positive evaluation of political leaders was also given by Tajikistan (63\%), Uzbekistan (55\%), Ukraine (52\%), Moldova (49\%) and Kyrgyzstan (49\%). There are clearly visible "compatriotic hints" as for many years L. Brezhnev worked in Ukraine, Kazakhstan and Moldova, where according to the information received, he left a good memory of himself. The youth showed significantly weaker knowledge of the historical figure and in this connection evaluations were more restrained comparing with those of the older generation.

The share of supporters of negative attitude to the personality of the first President of the USSR M. Gorbachev exceeded one-third of the total number of respondents surveyed in Kazakhstan, and accounted for $36 \%$, positive (27\%) or neutral (26\%) positions were equally distributed. Despite the fact that Gorbachev is one of the most famous figures, some young people often say they have not heard about such historical figure. Perhaps this explains the difference in the estimates of the youth and the older generation.

B. Yeltsin, the first President of Russia is perceived in independent Kazakhstan as head of a foreign state, and an attitude to him is somewhat different than to his predecessors. We can talk about the positive attitude towards this historical character and synchronicity in the estimates of young and older generation: $38 \%$ of respondents assess 
Yeltsin positively, 20\% negatively, 32\% neutrally and 7\% of respondents are undecided.

Young people are in general worse informed about such relatively modern politician as B. Yeltsin than the older generation.

Let us note that for a group of "local heroes" the attitude of Kazakhstan is definite and positive. Evaluation of Amangeldy Imanov, the organizer of national liberation uprising of Kazakh people in 1916; prominent public figures and statesmen Alikhan Bokeikhanov, Turar Ryskulov and Dinmuhammed Kunaev; poet, writer, literary critic Olzhas Suleimenov ranged from 0.6 to 0.8 . Herewith, the highest indices of positive attitude were stated as regards D. Kunaev and O. Suleimenov. In the meantime, sufficiently less number of respondents demonstrates their sympathy to T. Ryskulov. A. Bukeikhanov is sympathized only by $46 \%$ of respondents.

According to information of Gulmira Ileuova, who participated in project "Youth's perception of new independent states of the history of Soviet and postSoviet periods" the peculiarities of respondents from Kazakhstan, namely poly-ethnicity appeared in this group of questions. For example, Russians and representatives of other ethnic groups in the process of survey demonstrated a high degree of knowledge of historical characters of nation-wide degree of Soviet period, and at the same time they spoke about their ignorance of representatives of Kazakhstan history twice, or thrice more often, than Kazakhs. For example, the proportion of those who do not know A. Imanov among Russians amounted to 25\%, among other ethnos 27\% (among Kazakhs - 8\%). A number of people unknowing A. Bukeikhanov among Russians is $38 \%$, among others - $37 \%$ (among Kazakhs $17 \%)^{\frac{15}{5}}$.

\subsection{Results of Survey on Ideologemes}

Perception of certain ideologemes of Soviet history is also analyzed in present study. Ten pairs of value judgments have been formulated (each pair present opposite judgments) which contained an ideological interpretation of certain historical events and processes. Ideologemes cover a broad period of history from pre-Soviet to post-Soviet period.

- About national policy in the Russian Empire;

- About revolution and victory of Lenin and Bolsheviks in the Civil war;

- About industrialization;
- About collectivization;

- About Soviet-German treaty of 1939 (MolotovRibbentrop Pact);

- About the role of the USSR in liberation of people of Europe from Fascism;

- About Soviet foreign policy in Post-war period;

- About entrance of Soviet troops in Afghanistan;

- About the collapse of the Soviet Union

- About the history of the country in Post-Soviet Period (the Period of sovereign development)

Respondents were asked to express their agreement or disagreement with one of the judgments in each pair of ideologemes (or declare the agreement with the two judgments equally).

In this article the authors will consider only some pairs of ideologemes, which seem more interesting for them.

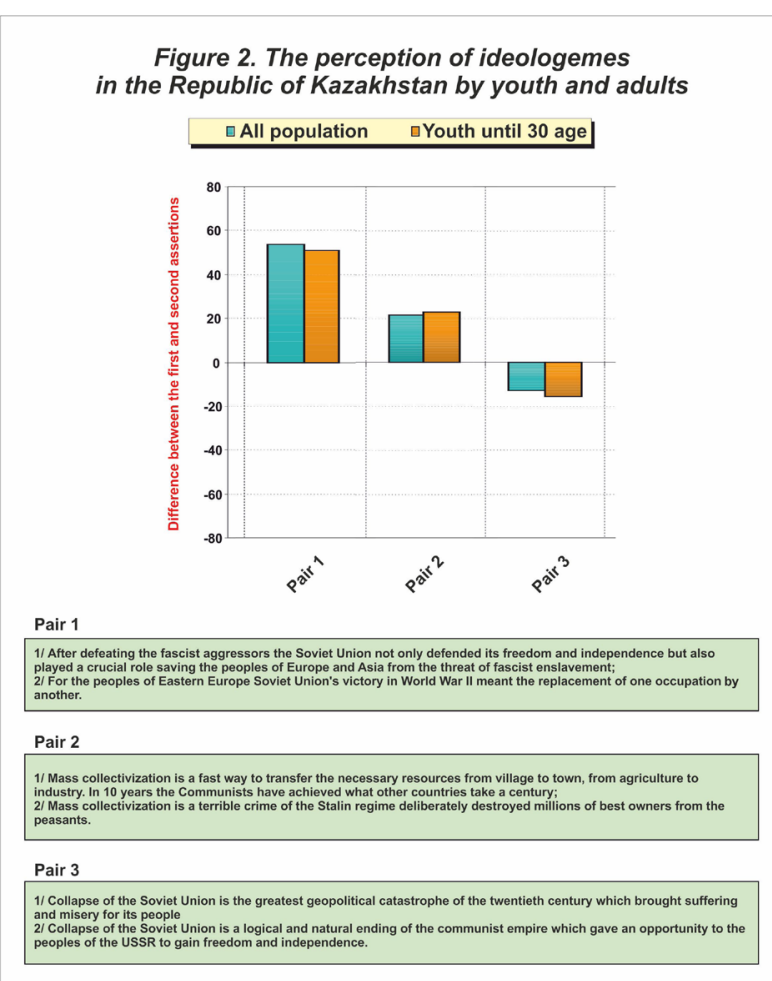

Figure 2. Perception of ideologemes in the Republic of Kazakhstan by youth and adults.

The analysis showed that even for such event as the Soviet victory in World War II contemporary historical interpretations are highly differentiated and far from being straightforward. Let us look at a pair of ideologemes: 
After defeating the fascist aggressors the Soviet Union not only defended its freedom and independence but also played a crucial role saving the peoples of Europe and Asia from the threat of fascist enslavement;

For the peoples of Eastern Europe the Soviet Union's victory in World War II meant the replacement of one occupation by another.

Analysis of these ideologemes showed that $65 \%$ of respondents from Kazakhstan agree with the first judgment, $13 \%$ are undecided and $11 \%$ are those who agree with the second judgment and agree equally with the first and second judgments. Here we see the retention of the "Soviet" understanding of this period of history. If we group the data by those who agree with a particular variant of the answer we get the following results: the first group will include countries, where up to $50 \%$ of respondents agree with the first judgment (Lithuania - 12\%, Estonia - 22\%, Georgia - 27\%, Latvia - 28\%, Moldova - 40\%, Azerbaijan - 49\%), the second group includes countries where more than $50 \%$ of respondents agree with the first judgment (Armenia - 55\%, Ukraine - 60\%, Kyrgyzstan - 63\%, Uzbekistan, Belarus - 66\%, Tajikistan $-67 \%$, Russia $-70 \%$ ). So countries of the first group agree to a lesser extent that the Soviet Union played a crucial role in saving the peoples of Europe and Asia from the threat of fascist enslavement and defended their freedom and independence. According to this classification Kazakhstan is included in the second group. We will note that practically all countries which are included in the first group have the governments focusing on the West and disposing negatively to the Soviet past of their countries. But existing difference of respondents' opinions of both the first and the second groups shows unambiguous feelings of population to the results of the USSR participation in the War.

For more unbiased assessment of the Soviet past we will demonstrate the examples of results of respondents' estimates of some more ideologemes. One of them is as follows:

First - Mass collectivization is a fast way to transfer the necessary resources from village to town, from agriculture to industry. During10 years the Communists have achieved what took a century in other countries;

Second - Mass collectivization is a terrible crime of the Stalin regime which deliberately destroyed millions of best farmers out of the peasants.

Respondents from Kazakhstan rated these ideologemes as follows: $44 \%$ agree with the first judgment,
$22 \%$ agree with the second judgment, $19 \%$ equally agree with the second and the first judgment and 14\% are undecided. The results showed that comprehension of collectivization as a "criminal adventure of Stalin regime" in the post-Soviet space is relatively wide. But a positive attitude of most respondents with the first attitude shows that, in spite of incurred sacrifices, people emphasize with understanding the aims which were pursued by the communist government. However, to make the analysis of mentioned data more objective we compare them with the results of other countries of Post-Soviet space.

The results of respondents' survey let us divide their answers into 2 groups: countries- participants of the survey that agree with the first statement (Azerbaijan - 29\%, Armenia - 37\%, Kyrgyzstan - 57\%, Russia - 34\%, Tajikistan - 44\%, Uzbekistan $42 \%)$, countries-participants of the survey that agree with the second statement (Estonia - 59\%, Ukraine $41 \%$, Moldova - 35\%, Lithuania - 52\%, Latvia - $41 \%$, Georgia - 31\%, Belarus - 34\%). According to this classification Kazakhstan is included in the first group. In such a way, the results of the survey make it clear that the attitude to the used statements in different countries of the former USSR is not unique today. This means that collective opinion has not yet been formed as for these statements and it does not give a possibility to arrive at a single estimate of the events.

Let us consider another example of respondents' assessments of the following pair of ideologemes:

The collapse of the Soviet Union is the greatest geopolitical catastrophe of the twentieth century which brought suffering and misery for its people: $65 \%$ of respondents from the Republic of Kazakhstan agreed with this statement.

The collapse of the Soviet Union is a consistent and natural end of the communist empire which gave an opportunity to the peoples of the USSR to gain freedom and independence. $11 \%$ of respondents from the Republic of Kazakhstan consented with this statement. The remaining $11 \%$ agreed with the second and the first judgments and $13 \%$ were undecided.

The results showed that the difference between those who agreed with the first and those who agreed with second judgments of this ideologemes pair indicate insignificant differences between the views of the entire population and young people of Kazakhstan. So the results of the survey demonstrated that in spite the fact that since the fall of the Soviet state more than 20 years have passed, the most part 
of the population in our country estimate the mentioned event as a tragedy up to now.

Comparison of the data on the perception of ideologemes of the Soviet history by youth and adults of the new independent states in whole did not reveal any major differences between them. Nevertheless, we can distinguish a pair of judgments in respect of which the difference in assessments between the youth and the entire population is relatively higher than for the other pairs of judgments. These judgments are about:

- Industrialization;

- The role of the Soviet Union in the post-war life in Eastern Europe;

- Foreign policy of the USSR;

- The collapse of the USSR.

On average, young people chose the second opinion in a pair more often than population in whole, i.e., youth agreed that "the victory of the Soviet Union in World War II means a change of one occupation to another for the peoples of Eastern Europe, that "rapid industrialization of the USSR is a criminal adventure of Stalin's regime", that "the Soviet Union was an aggressive state threatening the world" and that "the collapse of the Soviet Union is a consistent and natural end of the communist empire".

\section{Conclusion}

In our opinion, the basic conclusions of the article are as follows:

- In historical consciousness of population and youth in particular a stable interest in history is observed.

- Most of citizens of post-Soviet states and Kazakhstan in whole are satisfied with their current level of history knowledge.

As for the youth, a number of those who know the history of their country and region is less than among population in whole. Youth is somewhat worse informed about historical events of the Soviet period not so far but now lying outside the realm of their experience than the entire population in whole. This is confirmed by estimates of young respondents' knowledge of history - which are less than self-assessment of the entire population.

This may be due to the fact that while teaching history in school the Soviet period is paid to essentially less attention; and younger generation has no first-hand experience of 'the Soviet life'.
Youth of the post-Soviet space is more progressively moving away from the Soviet history, which becomes past, which lie outside the realm of their experience. As the results of investigation show many young respondents, according to them, have heard and know nothing about many outstanding figures of the $20^{\text {th }}$ century.

Comparison of the data on the perception of ideologemes of the Soviet history by youth and adult population did not reveal any significant differences between them. It is worth noting that the youth of the countries-participants in the project had trouble estimating a particular ideologeme in average more often than population in whole, (i.e. the option "I don't know" was chosen more often). This circumstance confirms the conclusion about lower historical information awareness of young people, herewith we certainly must bear in mind that ideological polarization, which is more peculiar to the older generation, is not appropriate to young people.

- Among factors which influenced the respondents' attitude while answering questions was an ethnic background that is actual today for Kazakhstan as a polytechnic state. Therewith, the degree of education of respondents became an important factor.

- Historical consciousness at the everyday level reflects not real factors as such, but an idea of them. For example, while deciding on their attitude to historical figures, an estimate of not personality as such takes place, but aggregate of his/her actions and activity, which influenced the course of history, and so the epoch in whole.

- At comparatively low information awareness of youth about historical events of the Soviet period, their estimates of these events do not much differ from valuation of the entire population. Degree of compliance with one or other historical interpretations, expressed by youth and adult population of Kazakhstan and post-Soviet countries is possible to be recognized as extremely high.

Apparently, those interpretations of the Soviet history are transferred in a family from senior to junior generation, and this factor remains quite viable as regards the formation of historical consciousness compared with the factor of school historical education and the factor of dominated information field. This in turn enables to make a conclusion that basic parameters of common attitudes in relation to important historical events remain unchanged. It means that historical consciousness shows 
visible stability and consistency. Thereupon, it was slightly influenced by changes which were sometimes essential in establishment press in the process of realization of politics of memory.

- As for the estimation of events of the 20th century by the adult population, it necessary to note that in this case the so called a short historical memory comes into action, when its many real participants are still alive and evidence of history is still an immediate part of a person's private life and thus people cannot certainly avoid their individual perception, their specific understanding and explanation.

\section{References}

1. Romanovsky NV. Historical sociology in structure of sociological cognition. Sociological Studies. 2000; 6:13.

2. Balta E, Demir S. History, Identity and Foreign Policy: Ottoman-Turkish Image in the Current History Textbooks of the Russian Federation. Bilig. Journal of Social Sciences of the Turkic World. 2016; 76:1-32. Available from: http:// www.egejfas.org/bilig/issue/25338/267577\#author535482.

3. Toshchenko ZT. Historical consciousness and historical memory. An Analysis of the current situation. Russian Studies in History. 2010; 49(1):37-52.

4. Ahonen S. Historical consciousness: a viable paradigm for history education? Journal of Curriculum Studies. 2005; 37(6):697-707.

5. Glencross A. Historical consciousness in International relations theory: A Hidden Disciplinary dialogue. Millennium Conference. 2010; 1-27.

6. Seixas P. University of Toronto Press: Theorizing Historical Consciousness. 2004.
7. Subrt J. Historical consciousness and the teaching of history in the Czech Republic. Studia Edukacyjne. 2013; 24:195-223.

8. Wang Z. Columbia University Press: Never Forget National Humiliation. Historical Memory in Chinese Politics and Foreign Relations. 2012.

9. Rusen J. Memory, history and the quest for the future. In Cajani L, Ross A. (Eds.): Trentham Books: History Teaching, Identities and Citizenship. European Issues in Children's Identity and Citizenship, CiCe. Stoke on Trent. 2007; 7:13-34.

10. Repina LP. Moscow: Drofa: History of historical cognition. Textbook for higher educational institutions. 2004.

11. Non-profit partnership "Eurasian Monitor". Perception of history of Soviet and post-Soviet periods by youth of new independent states. Short analytical essay. Autonomous noncommercial organization "Zadorin's sociological workshop". 2009.

12. Utenkov VM, Zakalin AS. About historical consciousness of student youth. SotsIs, 2000; 6:120-21.

13. Gorshkov MK, Davydova NM. Historical self-consciousness of Russians. Monitoring of Public Opinion. 2005; 73:20.

14. Kutykova IV. National history in students' consciousness: results of post-Soviet period of twenty years. Historical Psychology and Sociological History. 2013; 2:104.

15. Ileuova G. Main historical events of Kazakhstan in upbringing of the country's population. 2015. Date accessed: 15.12.2015: Available from: http://www. ofstrategy.kz/index.php/ru/research/socialresearch/ item/457-osnovnye-istoricheskie-sobytiya-kazakhstana-vvospriyatii-naseleniya-strany.

16. Konovalov A. Valuation degree of historical consciousness (studies in East Kazakhstan). Global International Scientific analytical project. 2015. Date accessed: 15.09.2015: Available from: http://gisap.eu/ru/node/59338. 